\title{
Penciptaan Iklim Komunikasi Organisasi (Tinjuan Peran Kepala Dinas Kearsipan dan Perpustakaan Kota Jambi)
}

\author{
Mohamad Muspawi*, Firman, Yeni Confristha Manullang \\ Prodi Administrasi Pendidikan FKIP Universitas Jambi \\ *correspondence email: muspawi01@gmail.com
}

\begin{abstract}
Abstrak. Penelitian ini bertujuan untuk mengetahui langkah-langkah kepala dinas dalam menciptakan iklim komunikasi yang kondusif di Dinas Kearsipan dan Perpustakaan Kota Jambi dan mendeskripsikan faktor pendukung dan penghambatnya. Menggunakan metode kualitatif dengan jenis penelitian studi kasus. Subjek penelitian adalah kepala Dinas, kepala bidang, pegawai, cleaning service dan petugas keamanan. Teknik pengumpulan data yaitu wawancara. Teknik analisis data yaitu reduksi data, penyajian data, dan penarikan kesimpulan. Hasil penelitian menunjukkan bahwa: (1) Langkah-langkah kepala dinas dalam menciptakan iklim komunikasi jika ditinjau dari dimensi iklim komunikasi seperti, dukungan, partisipasi pembuat keputusan, kepercayaan, keterbukaan dan keterusterangan dan pencapaian kinerja yang tinggi menghasilkan bahwa iklim komunikasi di situ sudah berjalan kondusif secara keseluruhan. Namun masih terdapat pegawai yang tidak melaksanakan pekerjaan yang diberikan. (2) Faktor pendukungnya yaitu dukungan dan motivasi kepala dinas terhadap bawahan serta menyiapkan sarana dan prasarana yang dibutuhkan dalam pekerjaan. Pimpinan juga melakukan monitoring dan menanyakan kendala yang dihadapi. Faktor penghambatnya yaitu tidak seimbangnya jumlah pegawai dengan pengawasan sehingga sering terjadi kesalahpahaman persepsi antar pimpinan dan pegawai maupun antar pegawai dalam penyampaian dan pelaksanaan tugas, terdapat pegawai yang melakukan pekerjaan tidak sesuai dengan tupoksinya, dan terdapat pula pegawai yang selalu sungkan terhadap pimpinan dan sesama rekan kerjanya yang mengakibatkan komunikasi susah terjalin.
\end{abstract}

Kata kunci: Iklim komunikasi, Peran kepala dinas

\begin{abstract}
This study aims to determine the steps taken by the head of the department in creating a conducive communication climate in the Jambi City Archives and Library Office and to describe the supporting and inhibiting factors. Using qualitative methods with the type of case study research. The research subjects were the head of the department, the head of the field, employees, cleaning service and security officers. Data collection techniques are interviews. Data analysis techniques are data reduction, data presentation, and drawing conclusions. The results showed that: (1) the steps taken by the head of the service in creating a communication climate when viewed from the dimensions of the communication climate such as support, decisionmaking participation, trust, openness and candor and the achievement of high performance resulted that the communication climate there was already running conducive overall. However, there are still employees who do not carry out the work given. (2) The supporting factors are the support and motivation of the head of service towards subordinates and preparing the facilities and infrastructure needed in the work. The leaders also monitor and ask about the obstacles they face. The inhibiting factor is the unbalanced number of employees with supervision so that there is often a misunderstanding of perceptions between leaders and employees as well as between employees in the delivery and implementation of tasks, there are employees who do work that is not in accordance with their main duties and responsibilities, and there are also employees who are always reluctant to their leaders and fellow workers which makes communication difficult.
\end{abstract}

Keywords: Communication climate, The role of the head of service

\section{PENDAHULUAN}

Komunikasi dalam suatu organisasi menjadi alat koordinasi yang akan menghasilkan informasi melalui suatu aliran sistem yang menghubungkan dan menghasilkan kinerja antar komponen di dalam organisasi itu sendiri. Iklim dan budaya organisasi dapat dibentuk oleh komunikasi dalam organisasi. Hal ini harus dipahami dengan baik agar perbedaan individu dan kesalahpahaman dalam organisasi dapat diminimalkan dan dikurangi sehingga konflik dapat dihindari.

Iklim komunikasi merupakan kombinasi dari persepsi evaluasi yang ekstensif terhadap kejadian, perilaku manusia, reaksi karyawan terhadap karyawan lain, ekspektasi, konflik antar karyawan dan peluang pertumbuhan dalam organisasi gabungan (Stevenson et al., 2017). Iklim komunikasi diciptakan oleh interaksi antar anggota organisasi. Interaksi dan proses yang membentuk, menciptakan kembali, mengubah dan menopang iklim adalah hal-hal yang harus menjadi prioritas dalam organisasi. Upaya yang dapat dilakukan oleh suatu organisasi adalah dengan menciptakan iklim kerja yang positif yang didukung oleh anggota organisasi, karena setiap individu dalam organisasi membutuhkan penyesuaian dan perbaikan secara bertahap untuk mencapai hasil yang maksimal dan bermanfaat bagi organisasi. Iklim komunikasi yang positif akan berdampak pada organisasi, dimana tujuan bersama tercapai sesuai harapan dengan didukung oleh karyawan yang berkinerja baik. Komunikasi yang efektif merupakan bagian penting bagi semua organisasi, oleh karena itu pemimpin organisasi dan komunikator dalam organisasi harus memahami dan menyempurnakan 
keterampilan komunikasinya (Walandouw \& Moelyono, 2014).

Salah satu aspek terpenting yang dibutuhkan untuk kelangsungan hidup kelompok atau organisasi yang sehat dan baik adalah kepemimpinan, sesuai dengan tujuan yang ditetapkan dalam pembentukan kelompok atau organisasi. Hal ini juga berlaku dalam sebuah organisasi kelembagaan, peran seorang pemimpin diperlukan untuk memberikan contoh dan arahan terhadap kegiatan sehari-hari di suatu lembaga atau layanan. Tanpa pemimpin, tujuan pribadi atau organisasi akan menimbulkan kendala serius jika tidak ada yang mengarahkannya. Yuliani \& Kristiawan (2016) sebagaimana yang dikutip oleh Muspawi (2020) mengatakan bahwa eksistensi kepemimpinan menyangkut sebuah proses pengaruh sosial yang dalam hal ini pengaruh yang dijalankan oleh seseorang secara sengaja terhadap orang lain untuk menstruktur aktivitas serta hubungan di dalam suatu organisasi atau kelompok. Greenberg \& Baron (1995) mengatakan pemimpin adalah seseorang yang menciptakan atau membuat strategi dalam suatu organisasi untuk mencapai tujuan bersama. Oleh karena itu, kepemimpinan di suatu instansi pemerintah atau swasta merupakan nilai yang sangat dibutuhkan. Komunikasi yang baik merupakan kunci kelangsungan hidup organisasi yang sehat, baik secara formal maupun informan. Komunikasi antara karyawan dengan pimpinan serta antara karyawan dengan karyawan sangat penting karena komunikasi dapat diibaratkan sebagai jembatan interaksi yang memberikan informasi bagi semua orang, sehingga berdampak positif bagi suatu organisasi. Jika tidak ada komunikasi, tidak mungkin terjadi koordinasi dan kerjasama, karena karyawan tidak dapat mengetahui apa yang dilakukan rekan kerjanya, pemimpin tidak dapat menerima informasi serta memberikan arahan dan intruksi. Mencapai tujuan tanpa kolaborasi tidak mungkin tanpa komunikasi, karena karyawan tidak dapat menyampaikan kebutuhan dan perasaannya kepada pimpinan dan kolega.

Studi awal penelitian ini menginformasikan bahwa kondisi iklim komunikasi organisasi pada Dinas Kearsipan dan Perpustakaan Kota Jambi masih perlu mendapat perhatian serius, ditemukan bahwa komunikasi sesama pegawai dalam hal melakukan pekerjaan masih kurang terjalin, oleh karena itu melalui penelitian ini penulis berupaya menelaah bagaimana peran kepala dinas dalam penciptaan iklim komunikasi organisasi di kantor tersebut.

\section{METODE}

Penelitian ini menggunakan pendekatan deskriptif kualitatif dengan jenis penelitian studi kasus (case study). Penelitian studi kasus yang dikemukakan oleh Creswell (2010) adalah strategi penelitian dimana peneliti secara cermat menyelidiki suatu peristiwa, kegiatan, program, proses atau sekelompok individu. Namun jenis penelitian studi kasus ini dibatasi oleh aktivitas dan waktu. Peneliti dapat sepenuhnya mengumpulkan informasi data yang diperlukan dengan menggunakan prosedur pengumpulan data yang berbeda berdasarkan waktu yang telah ditentukan. Teknik pengumpulan data yang digunakan adalah observasi dan wawancara. Untuk mengecek keabsahan data peneliti menggunakan triangulasi yaitu dengan cara membandingkan dan mengecek tingkat kepercayaan atau informasi yang diperoleh melalui alat dan waktu yang berbeda. hal-hal yang dimaksud meliputi: (1) Membandingkan data wawancara, (2) Membandingkan apa yang menjadi perhatian partisipan di depan umum dengan apa yang disajikan secara pribadi, (3) Membandingkan situasi apa yang dipikirkan partisipan dengan situasi penelitian dari waktu ke waktu (4) Membandingkan keadaan dan cara pandang seseorang dengan pendapat dan pandangan yang berbeda. Teknik analisis data sebagai berikut: (1) reduksi data (data reduction), (2) penyajian data (data display), (3) penarikan kesimpulan dan verifikasi (conclusion drawing/verifying).

\section{HASIL DAN PEMBAHASAN}

Hasil penelitian menunjukkan bahwa peran kepala dinas kearsipan dan perpustakaan kota Jambi dalam menciptakan iklim komunikasi organisasi sebagai berikut:

\section{Dukungan}

Agar pekerjaan dapat dilakukan dengan baik, hal yang harus dilakukan pimpinan adalah memberi dukungan terhadap pegawai agar pegawai merasa bahwa dirinya di perhatikan oleh pimpinan. Berdasarkan hasil penelitian di Dinas Kearsipan dan Perpustakaan Kota Jambi dukungan dari pimpinan yaitu melakukan monitoring terhadap pekerjaan yang dilakukan bawahan dan menanyakan kendala yang dihadapi seperti apa. Tidak hanya itu, dukungan yang diberikan kepala dinas adalah dimulai dari hal sederhana yaitu saling bertegur sapa ketika bertemu. Kepala dinas tidak selalu hanya berada dalam ruangan/atas meja beliau selalu mengecek ke bawah dan berkunjung keruangan-ruangan. ia juga memberikan dukungan berupa sarana prasarana yang dibutuhkan dalam pelaksanaan pekerjaan agar tujuan bersama dapat tercapai.

Hal ini memiliki kesamaan dengan penelitian yang dilakukan oleh Hapsari (2015) yang mengatakan bahwa dukungan yang terjalin dapat berupa interaksi yang bentuknya saling menyapa satu sama lain. Hal ini sejalan dengan pendapat Yuli (2005) mengatakan bahwa seseorang (pemimpin) dapat memengaruhi orang lain untuk bekerjasama melaksanakan pekerjaan yang berkaitan agar mencapai tujuan bersama. Komunikasi yang efektif, apabila dalam berkomunikasi menunjukkan 
sifat saling mendukung. Hal ini sesuai dengan pernyataan Armstrong (1998) Support is a feeling related to providing support from both superiors and colleagues. Dukungan dari pimpinan merupakan salah satu cara agar memotivasi para pegawai melaksanakan pekerjaannya. Ditambah lagi dengan pernyataan Likert (2005) yang menyatakan bahwa setiap hubungan antar pimpinan menunjukkan sifat mendukung dan membangun sehingga merasa bahwa dirinya berharga dalam organisasi. Jika para pegawai merasakan dirinya telah dianggap penting dan berharga oleh pimpinan, maka para pegawai akan memberikan hasil yang maksimal.

\section{Partisipasi pengambilan keputusan}

Hasil penelitian menginformasikan bahwa pimpinan dinas kearsipan dan perpustakaan kota Jambi terkait dalam pengambilan keputusan dapat dikatakan melibatkan bawahan dalam pengambilan keputusan. Pimpinan selalu mendengarkan pendapat bawahan kemudian dipertimbangkan sebelum diputuskan. Dalam pengambilan suatu keputusan dirapatkan terlebih dahulu agar keputusan yang akan ditetapkan dapat berjalan dengan maksimal. Selanjutnya keputusan yang diambil oleh kepala dinas dilakukan koordinasi sesuai dengan ketentuan yang ada, meskipun semua sudah diatur berdasarkan tupoksi bawahan karena tidak semua permasalahan atau keputusan pimpinan melibatkan semua bawahan, dimana ada hal-hal tertentu yang tidak melibatkan bawahan seperti membahas mengenai anggaran dan lain sebagainya.

Berdasarkan wawancara yang dilakukan peneliti terhadap kepala dinas yang mengatakan bahwa ketika ada kepentingan urgent dan membutuhkan keputusan yang cepat saat itu juga maka pimpinan tidak melibatkan bawahan dalam pengambilan keputusan. Namun, pengambilan keputusan yang menyangkut kebijakan dan pekerjaan, kepala dinas sangat terbuka dan mengharapkan pegawai memberikan masukan agar tercapainya tujuan bersama. Hasil penelitian ini sejalan dengan penelitian yang dilakukan oleh Susilawati (2010) bahwa setiap karyawan memang diharapkan untuk berpartisipasi dalam membuat keputusan ketika rapat untuk memecahkan suatu masalah. Setelah keputusan diambil, manager mengemukakan program kerja yang telah diputuskan ke forum direksi. Latifah (2016) melaporkan bahwa kepala sekolah SDIT Al-Bayyinah Garut melibatkan para guru dalam mengambil keputusan. Kusuma (2017) melaporkan bahwa pimpinan di perusahaan PT PLN (Persero) APJ Surakarta juga melibatkan jajarannya dalam mengambil keputusan.

Hal ini sesuai dengan pendapat Pace dan Faules (2002) seluruh pegawai di semua tingkat harus diberikan kesempatan berkomunikasi dengan manajemen di atas mereka agar berperan serta dalam proses pembuatan keputusan. Komunikasi dan koordinasi merupakan peran penting dalam pengambilan keputusan agar tidak memberikan dampak negatif untuk Dinas Kearsipan dan Perpustakaan Kota Jambi kedepannya.

\section{Kepercayaan}

Tercapainya hasil pekerjaan yang dilakukan bawahan tidak terlepas dari kepercayaan yang diberikan pimpinan. Kepercayaan merupakan aspek yang cukup penting dalam membentuk hubungan timbal balik yang positif antara pimpinan dan bawahan. Berdasarkan hasil penelitian ditemukan bahwa kepercayaan dari pimpinan sudah dirasakan oleh pegawai, dengan pimpinan memberikan tugas kepada pegawai itu sudah menunjukkan bahwa pimpinan percaya terhadap bawahannya. Namun, masih ada pegawai yang menyalahgunakan kepercayaan yang diberikan pimpinan dengan tidak melakukan pekerjaan sesuai dengan tugasnya. Seperti contoh, pimpinan memberikan kepercayaan kepada pegawai untuk melakukan monitoring turun lapangan kepada Organisasi Perangkat Daerah (OPD) memantau sejauh mana kegiatan arsip sudah dilakukan. Namun pegawai tidak mengindahkannya dan melakukan kepentingan pribadi.

Tingkat kepercayaan yang positif akan mampu menunjukkan kerja yang efektif dan efisien. setiap pegawai percaya akan kemampuan satu sama lain, dan memiliki tujuan yang sama untuk mencapainya. Sebaliknya jika kepercayaan tidak terjalin dengan baik maka akan terdapat anggota yang tidak menunjukkan kinerjanya dan akan memberikan dampak negatif untuk kedepannya. Hal ini sesuai dengan pernyataan Suranto (2011) jika pemimpin dipercaya oleh pegawai maka akan lebih mudah menyampaikan pesan dan mempengaruhi sikap orang lain. Karena dengan percaya akan mempermudah tercapainya tujuan bersama.

\section{Keterbukaan dan keterusterangan}

Berdasarkan hasil penelitian dapat dikemukakan bahwa terkait keterbukaan dan keterusterangan temuan di dinas kearsipan dan perpustakaan kota Jambi sudah terlaksana sebagaimana mestinya. Pimpinan selalu terbuka mengenai pekerjaan namun ada beberapa hal yang tidak disampaikan pimpinan ke bawahan seperti pembahasan yang hanya melibatkan kepala bidang dan tidak kepada pegawai secara umum. Pimpinan selalu terbuka akan program kerja yang akan dilaksanakan, karena jika tidak ada keterbukaan dan keterusterangan akan menghambat pekerjaan. Jika ada suatu kendala yang dialami oleh pimpinan ataupun bawahan akan menjadi terhambat jika tidak disampaikan dan tidak mencari solusinya bersama, karena pada dasarnya keterbukaan dan keterusterangan akan menghilangkan kesalahpahaman. Kepala dinas sudah cukup terbuka mengenai pekerjaan yang akan dilakukan dan juga kepala dinas selalu menerima saran dan keluhan dari pegawainya. Keluhan yang dimaksud adalah ketika 
pegawai mengalami kendala dalam melakukan pekerjaan dimana dibutuhkan penambahan sarana prasarana untuk mendukung tercapainya tujuan, seperti contoh pegawai menyampaikan kendala dan memberikan saran kepada kepala bidang untuk menambahkan printer agar proses pencetakan berkas arsip dapat selesai pada waktunya, lalu kepala bidang akan menyampaikan keluhan dan saran tersebut kepada kepala dinas kemudian akan dipertimbangkan dan di diskusikan bersama.

Hasil ini sejalan dengan pernyataan Suranto (2011) keterbukaan adalah sikap yang dapat menerima masukan dari orang lain, serta bersedia menyampaikan informasi kepada orang lain. Dalam iklim komunikasi, keterbukaan dan keterusterangan akan memberikan dampak positif akan sebuah organisasi. Seorang pemimpin akan mendengarkan apa yang disampaikan oleh pegawainya, begitupun sebaliknya. Hal ini juga sejalan dengan penelitian yang dilakukan oleh Silvia Noviani (2017) keterbukaan dalam komunikasi kebawah dilihat dari kemudahan anggota organisasi untuk berkoordinasi, mendengarkan dalam komunikasi kebawah dilihat dari atasan yang terbuka untuk berdiskusi dan mendengarkan saran dari bawahan. Berdasarkan temuan penelitian ini, penulis melihat para pegawai tidak canggung bertanya jika ada kesulitan terhadap sesama rekan kerja maupun pimpinan. Keterbukaan dalam komunikasi kebawah dilihat dari kemudahan anggota organisasi untuk berkoordinasi, mendengarkan dalam komunikasi ke bawah dilihat dari atasan yang terbuka untuk berdiskusi dan mendengarkan saran dari bawahan. Kurangnya sifat terbuka di antara pimpinan dan bawahan akan menyebabkan pemblokan atau tidak mau menyampaikan pesan dan gangguan dalam pesan.

\section{Pencapaian kinerja yang tinggi}

Pencapaian kinerja yang tinggi tidak terlepas dari dukungan dan motivasi yang diberikan pimpinan terhadap bawahannya. Pegawai akan menunjukkan hasil yang terbaik jika dia merasa diperhatikan oleh pimpinan. Jika pekerjaan yang dilakukan baik maka akan berdampak juga terhadap tujuan yang sudah ditetapkan. Di semua tingkat organisasi setiap anggota harus memiliki komitmen terhadap kinerja yang tinggi dan berkualitas (Pace \& Faules, 2002). Agar tercapainya kemajuan suatu organisasi, pimpinan berusaha mencari cara agar memperoleh kinerja yang baik dari pegawainya, caranya dengan memberikan pemahaman mengenai visi misi. Berdasarkan pengamatan, peneliti sudah melihat template yang berisi visi misi Dinas Kearsipan dan Perpustakaan Kota Jambi di depan ruangan kepala dinas. Oleh karena itu, untuk mencapai visi misi tersebut maka sangat membutuhkan dukungan dan motivasi dari pimpinan dan sesama rekan kerja.

Hasil penelitian menunjukkan bahwa kepala dinas kearsipan dan perpustakaan kota Jambi sudah memberikan dukungan dan motivasi terhadap pegawainya. Dukungan yang diberikan berupa menyiapkan sarana dan prasarana yang dibutuhkan, dan juga pimpinan memberikan motivasi agar pegawai melakukan pekerjaan dengan baik. Hal ini sesuai dengan pernyataan Fuad (2006) motivasi adalah proses pemberian pola (penggerak) kepada pegawai agar dapat bekerjasama sehingga tujuan organisasi dapat tercapai secara efisien dan efektif.

Namun, berdasarkan hasil temuan masih ada beberapa pegawai yang lebih mementingkan kepentingan pribadi dan tidak melakukan pekerjaan yang diberikan pimpinan kemudian akan berdampak pada kepentingan dinas kearsipan dan perpustakaan kota Jambi. Koordinasi yang kurang baik dapat ditutupi dengan komunikasi antar rekan kerja dan pimpinan. Banyak media yang dapat digunakan dalam berkomunikasi seperti telepon dan grup Whattsapp untuk menyelesaikan permasalahan yang ada. Seorang pemimpin dapat dipandang efektif apabila dapat mempengaruhi pegawainya untuk meninggalkan kepentingan pribadi demi keberhasilan organisasi, motivasi dalam melakukan pekerjaan sangat berpengaruh terhadap peningkatan kerja pegawai. Berkurangnya motivasi kerja, akan berdampak pada kinerja yang diberikan oleh karena itu perlu dihindari.

\section{Pembahasan}

\section{Faktor pendukung dalam menciptakan iklim komunikasi organisasi di Dinas Kearsipan dan Perpustakaan Kota Jambi}

Faktor pendukung pimpinan dalam menciptakan komunikasi di dinas kearsipan dan perpustakaan kota Jambi yaitu kepala dinas memberikan dukungan dan motivasi terhadap bawahannya, menyiapkan sarana dan prasarana yang dibutuhkan dalam menjalankan tugas. Tidak hanya itu, pimpinan juga melakukan monitoring terhadap bawahan dan menanyakan kendala apa yang dihadapi, monitoring dilakukan kepala dinas dengan melihat kinerja pegawai melalui CCTV dan juga dengan berkunjung ke ruangan-ruangan tiap bidang. Dinas kearsipan dan perpustakaan kota Jambi juga sudah memiliki sarana prasarana yang mendukung terjalinnya komunikasi yang efektif, seperti sudah mempunyai grup Whatsaap yang sangat berfungsi untuk menjalin koordinasi terhadap pimpinan dan pegawai. juga sudah tersedia wifi di beberapa titik agar komunikasi tidak terhambat oleh jaringan. Disamping itu, juga sering dilakukan kegiatan bersama-sama dengan asas kekeluargaan seperti melakukan pengajian bersama pada hari kamis, jika ada yang sakit dijenguk, dan setiap hari jumat melakukan gotong royong yang melibatkan semua pegawai sehingga komunikasi akan selalu terjalin dan hubungan antara pimpinan dan pegawai menjadi semakin erat dan harmonis. 
Hal ini sesuai dengan pernyataan Pace \& Faules (2002) yang mengatakan bahwa ada empat faktor yang mempengaruhi keberlangsungan iklim komunikasi yaitu: anggota organisasi, pekerjaan dalam organisasi, struktur organisasi dan pedoman organisasi. Hubungan pimpinan dan bawahannya merupakan interaksi untuk menciptakan lingkungan yang dapat memotivasi karyawan. Tidak hanya itu, faktor pendukung dalam menciptakan iklim komunikasi yang kondusif di dinas kearsipan dan perpustakaan kota Jambi juga didukung oleh kelengkapan administrasi seperti, sudah memiliki struktur organisasi yang jelas, pedoman organisasi seperti visi misi, dan anggota organisasi yang memiliki peran untuk menciptakan iklim komunikasi, sehingga iklim komunikasi dapat berjalan kondusif tergantung dari persepsi dan pemahaman yang diberikan oleh pimpinan terhadap pegawainya.

\section{Faktor Penghambat dalam menciptakan iklim komunikasi organisasi di Dinas Kearsipan dan Perpustakaan Kota Jambi}

Berdasarkan hasil penelitian dapat disampaikan bahwa faktor penghambat pimpinan dalam menciptakan iklim komunikasi di dinas kearsipan dan perpustakaan kota Jambi yaitu sering terjadi kesalahpahaman antar pimpinan dan pegawai bahkan pegawai antar pegawai dalam penyampaian dan pelaksanaan tugas, dan masih ada pegawai yang melakukan pekerjaan tidak sesuai dengan tupoksinya, pegawai yang tidak berada di ruangan berpengaruh pada hal yang perlu disampaikan menjadi terhambat, masih ada pegawai yang merasa sungkan terhadap pimpinan dan sesama rekan kerja nya yang membuat komunikasi susah disampaikan.

Hal ini senada dengan pernyataan yang disampaikan oleh Marhaeni (2009) ada beberapa hambatan dalam proses komunikasi, yaitu: a. Hambatan dari pengirim pesan, misalnya pesan yang akan disampaikan belum jelas bagi dirinya atau pengirim pesan, hal ini dipengaruhi oleh perasaan atau situasi emosional sehingga mempengaruhi motivasi, yaitu mendorong seseorang untuk bertidak seseuai keinginan, kebutuhan atau kepentingan. b. Hambatan dalam penyandian/simbol. Hal ini dapat terjadi karena bahasa yang dipergunakan tidak jelas sehingga mempunyai arti lebih dari satu, bahasa yang dipergunakan antara si pengirim dan si penerima terlalu sulit. c. Hambatan media, merupakan hambatan yang terjadi dalam penggunaan media komunikasi. d. Hambatan dari penerima pesan, kurangnya perhatian pada saat menerima/mendengarkan pesan, tanggapan yang keliru dan tidak mencari informasi lebih lanjut. Jadi dalam berkomunikasi, penting ketika orang yang sedang melakukan komunikasi tidak hanya mendengarkan informasi yang akan disampaikan, melainkan juga harus memperhatikan siapa yang menyampaikan. Dan jika ada keliru atau kurang paham dalam mendengarkan informasi yang disampaikan pemimpin atau rekan kerja dapat mencari informasi lebih lanjut kepada orang yang bersangkutan.

Temuan penelitian ini juga menginformasikan bahwa yang menjadi faktor penghambat terciptanya iklim komunikasi yaitu: terjadi kesalahpahaman dalam penyampaian tugas seperti pemimpin memberikan tugas membuat nota dinas dengan format yang diberikan pimpinan namun yang melaksanakan tugas tidak membuat nota dinas seperti yang diharapkan oleh pimpinan dan juga terdapat pegawai yang melaksanakan pekerjaan tidak sesuai dengan tugasnya. Hal tersebut berpengaruh dengan tujuan yang akan dicapai. Hambatan yang terjadi ada kaitannya dengan jumlah pegawai yang berada di Dinas Kearsipan dan Perpustakaan Kota Jambi yaitu terdiri dari kepala dinas, sekretaris, 4 orang kepala bidang, dan 82 orang pegawai PNS dan PTT. Dimana dengan jumlah pegawai yang cukup banyak akan membuat pengawasan dan komunikasi kepala dinas terhadap pegawai yang akan mengakibatkan sering terjadi kesalahpahaman dalam menyampaikan pekerjaan.

\section{SIMPULAN}

Berdasarkan hasil penelitian dan pembahasan penelitian yang telah disampaikan maka dapat disampaikan kesimpulan sebagai berikut: 1. Langkahlangkah yang dilakukan kepala dinas dalam menciptakan iklim komunikasi yang ditinjau dari pembentuk iklim komunikasi seperti, dukungan, partisipasi pembuat keputusan, kepercayaan, keterbukaan dan keterusterangan dan tujuan kinerja yang tinggi, memberikan hasil bahwa iklim komunikasi antara pimpinan dan pegawai berjalan kondusif secara keseluruhan. Namun masih ada pegawai yang menyalahgunakan kepercayaan pimpinan dengan tidak melaksanakan pekerjaan yang diberikan. 2. Faktor pendukung dalam menciptakan iklim komunikasi yaitu pimpinan memberikan dukungan dan motivasi terhadap pegawainya serta menyiapkan sarana dan prasarana yang dibutuhkan dalam pekerjaan. Pimpinan juga melakukan monitoring dan menanyakan kendala yang dihadapi oleh pegawainya dalam melaksanakan pekerjaan. 3. Faktor penghambat dalam menciptakan iklim komunikasi yaitu tidak seimbangnya jumlah pegawai dengan pengawasan yang dilakukan oleh pimpinan sehingga sering terjadi kesalahpahaman dalam penyampaian tugas yang diberikan terhadap pegawai, kesalahpahaman terjadi antar pimpinan dan pegawai bahkan pegawai antar pegawai dalam penyampaian dan pelaksanaan tugas, terdapat pegawai yang melakukan pekerjaan tidak sesuai dengan tupoksinya, dan masih ada pegawai yang merasa tidak enak terhadap pimpinan dan sesama rekan kerja nya yang mengakibatkan komunikasi susah disampaikan. 


\section{DAFTAR PUSTAKA}

Armstrong M. (1998). Manajemen sumber daya manusia. Media Kompetindo, Jakarta.

Creswell, J. W. (2010). Research design pendekatan kualitatif, kuantitatif, dan mixed. Yogyakarta: Pustaka Pelajar.

Fuad, M (2006). Pengantar Bisnis. Jakarta: Gramedia Pustaka Umum.

Greenberg, J., \& Baron, R. A. (1995). Behavior in organization. New Jersey: PrenticeHall.

Hapsari, Elisa (2015). Iklim komunikasi organisasi dalam childhood cancer. Skripsi. Universitas Sebelas Maret.

Kusuma, Satria (2017). Iklim Komunikasi Organisasi dan Motivasi Kerja Pimpinan dalam Mewujudkan Misi Perusahaan. Jurnal Perspektif. Universitas Muhammadiyah Jakarata. Vol. 1 No. 1 Januari Juni 2017.

Latifah, Hanny (2016). Membangun Iklim Komunikasi Organisasi Dalam Upaya Optimalisasi Kinerja Guru. Jurnal Komunikasi Hasil Pemikiran dan Penelitian -ISSN: 2461-0836. Volume. 2 No. 2 Oktober 2016: 102.

Likert (2005). Human communication: Konteks-konteks komunikasi. Bandung: Remaja Rosdakarya

Marhaeni, Fajar. (2009). Ilmu komunikasi, teori dan praktik. Bandung: Remaja Rosdakarya.

Muspawi, Mohamad. (2020). Strategi Menjadi Kepala Sekolah Profesional. Jurnal Ilmiah Universitas Batanghari Jambi, 20(2), Juli 2020, 402-409

Noviani, S. (2017). Iklim komunikasi organisasi pada bidang kantor pengolahan di PT. Perkebunan Nusantara VIII (Perkebunan Montaya). Disertasi. Universitas Padjadjaran Bandung.

Pace RW \& Faules D (2002). Komunikasi organisasi strategi meningkatkan keja perusahaan, Bandung: Remaja Rosdakarya.

Stevenson, Kathryn T, Tasha L. King, Kathryn R. Selm, M. Nils Peterson \& Martha C. Monroe. 2017. Framing climate change communication to prompt individual and collective action among adolescents from agricultural communities. Environmental Education Research ISSN: 13504622 (Print) 1469-5871

Suranto, Aw (2011). Komunikasi interpersonal. Yogyakarta: Graha Ilmu

Susilawati, F. (2010). Komunikasi organisasi dalam kepemimpinan pada PT Tempo Inti Media. Skripsi. UIN Syarif Hidayatullah.

Yuli, C. (2005). Manajemen sumber daya manusia. Malang: Universitas Muhammadiyah

Walandouw, Adelin \& Herry Moelyono. 2014. Iklim komunikasi organisasi dalam meningkatkan kinerja karyawan di perusahaan manado post. Journal "Acta Diurna" Volume III. No.2. Tahun 2014. 